\title{
RASIO KECUKUPAN MODAL DAN BIAYA OPERASIONAL SEBAGAI FAKTOR PENENTU PROFITABILITAS BANK UMUM SYARIAH DI INDONESIA
}

\author{
Oleh: Nugraha ${ }^{1}$ dan Nuni Ayu Warawiati \\ (UNIVERSITAS PENDIDIKAN INDONESI) \\ ${ }^{1)}$ nugraha@upi.edu
}

\begin{abstract}
Abstrak-Penelitian ini bertujuan untuk menguji pelaksanaan pembiayaan bagi hasil dalam kegiatan utama Perbankan syariah di Indonesia, yang dikonstruksikan dengan menguji hubungan antara Rasio Kecukupan Modal (CAR) dan Rasio Biaya Operasional (BOPO) dengan Profitabilitas Bank Umum Syariah di Indonesia. Data yang digunakan adalah data panel, yang diambil Laporan Keuangan Bank Umum Syariah yang terdaftar di Otoritas Jasa Keuangan (OJK) selama tahun 2012-2017. Teknik analisis data yang digunakan adalah analisis regresi linier berganda. Hasil penelitian menunjukan bahwa Rasio Kecukupan Modal dan Rasio BOPO merupakan dua faktor yang menentukan Tingkat Profitabilitas Bank Umum Syariah di Indonesia. Hal ini juga dapat menjelaskan bahwa kegiatan perbankan syariah di Indonesia, sampai dengan saat ini tetap terfokus dan didominasi oleh kegiatan yang berbasis pelaksanaan fungsi intermediasi Bank. Namun hal ini juga sekaligus menunjukan bahwa fungsi pembiayaan yang berbasis bagi hasil, sebagai hakikat utama perbankan syariah belum mampu dijalankan oleh Bank Umum Syariah di Indonesia.
\end{abstract}

Kata Kunci: Kecukupan Modal, BOPO, Profitabilitas, dan Pembiayaan Bagi Hasil.

\begin{abstract}
This research aims to test the implementation of the profit and loss sharing principle as the main activity of Islamic banking in Indonesia, which is constructed by testing the relationship between the Capital Adequacy Ratio (CAR) and Operational Cost Ratio. The data used is the panel data, taken from financial reports of Islamic Banking, registered in The Indonesia Financial Services Authority during the years 2012-2017. Data analysis technique used was multiple linear regression. Research results show that the Capital Adequacy Ratio and Operational Cost are determine of profitability of Islamic banking in Indonesia. It can be explained that the activities of Islamic banking in Indonesia, still focused and dominated by activity based on intermediary banks function. But it also showed the profit and loss sharing principle, as a the main activity of Islamic banking hasn't been able to run by Islamic Bank in Indonesia.
\end{abstract}

Keywords: Capital adequacy, Profitability, OCOR, and Profit and loss sharing principle

\section{PENDAHULUAN}

Secara statistik pertumbuhan perbankan syariah di Indonesia dinilai cukup tinggi pertumbuhannya.

Sesuai dengan data OJK, per bulan 
Januari 2018, terdiri dari 13 Bank Umum Syariah (BUS), 21 Unit Usaha Syariah (UUS), dan 167 Bank Perkreditan Rakyat Syariah (BPRS).

Kehadiran perbankan syariah semestinya menjadi satu alternatif pembiayan yang menguntungkan. Terutama dengan adanya prinsip bagi hasil (loss profit sharing) sebagai prinsip utama perbankan syariah (Al-Harran, 1995).

Sistem bagi hasil selain dipandang tidak mengandung riba, sehingga sesuai dengan prinsip ajaran agama islam, juga dirasa lebih "adil" bagi nasabah, karena keuntungan dan kerugian akan terbagi secara proporsional di antara bank syariah dengan nasabah (Chapra, 2008).

Namun fenomena yang ada menunjukan justru perbankan syariah di Indonesia belum sepenuhnya menjalankan prinsip bagi hasil ini
(Jaelani, 2015). Perbankan syariah di dunia pun masih terjebak dalam fungsi utama intermediasi bank, yaitu menampung dan mendistribusikan dana (Alharbi, 2015).

Penelitian ini merupakan upaya untuk melakukan pengujian praktek perbankan syariah di Indonesia. Khususnya, dalam kaitan dengan pelaksanaan prinsip bagi hasil. Untuk pengujian hal tersebut, dikonstruksikan dengan menguji faktor yang menentukan profitabilitas perbankan syariah di Indonesia.

Dalam penelitian ini profitabilitas diukur dengan menggunakan rasio Return on Asset (ROA). Sebagai informasi awal, berikut ini adalah nilai ROA Bank Umum Syariah Indonesia.

Tabel 1. Nilai ROA Bank Umum Syariah Tahun 2012-2017 Dalam persen (\%)

\begin{tabular}{|l|c|c|c|c|c|c|c|}
\hline \multicolumn{1}{|c|}{ Nama Bank } & $\mathbf{2 0 1 2}$ & $\mathbf{2 0 1 3}$ & $\mathbf{2 0 1 4}$ & $\mathbf{2 0 1 5}$ & $\mathbf{2 0 1 6}$ & $\mathbf{2 0 1 7}$ & Rata-rata \\
\hline PT Bank Aceh Syariah & - & - & - & - & - & 2,51 & 2,51 \\
\hline PT Bank Muamalat Indonesia & 1,54 & 0,50 & 0,17 & 0,20 & 0,22 & 0,11 & 0,46 \\
\hline PT Bank Victoria Syariah & 1,43 & 0,50 & $-1,87$ & $-2,36$ & $-2,19$ & 0,36 & $-0,69$ \\
\hline PT BRI Syariah & 0,88 & 1,15 & 0,08 & 0,77 & 0,95 & 0,51 & 0,72 \\
\hline PT Bank Jabar Banten Syarial & $-0,59$ & 0,91 & 0,41 & 0,49 & 0,63 & 0,63 & 0,41 \\
\hline PT BNI Syariah & 1,48 & 1,37 & 1,27 & 1,43 & 1,44 & 1,31 & 1,38 \\
\hline PT Bank Syariah Mandiri & 2,25 & 1,53 & $-0,04$ & 0,56 & 0,59 & 0,59 & 0,91 \\
\hline PT Bank Mega Syariah & 3,81 & 2,33 & 0,29 & 0,30 & 2,63 & 1,56 & 1,82 \\
\hline PT Bank Panin Syariah & 3,48 & 1,03 & 1,99 & 1,14 & 0,37 & $-10,77$ & $-0,46$ \\
\hline PT Bank Syariah Bukopin & 0,55 & 0,69 & 0,27 & 0,79 & $-1,12$ & 0,02 & 0,20 \\
\hline PT BCA Syariah & 0,80 & 1,00 & 0,80 & 1,00 & 1,10 & 1,20 & 0,98 \\
\hline PT Maybank Syariah Indones & 2,88 & 2,87 & 3,61 & $-20,13$ & $-9,51$ & 5,50 & $-2,46$ \\
\hline PT BTPN Syariah & - & - & 3,60 & 3,10 & 3,10 & 2,10 & 2,98 \\
\hline Rata-rata Per Tahun & 1,68 & 1,26 & 0,88 & $-1,06$ & $-0,15$ & 0,26 & \\
\hline
\end{tabular}

Sumber: Annual Report (data diolah) 
Dari tabel di atas juga ditunjukan bahwa sebagian besar perbankan syariah belum mampu memenuhi standar ROA,yakni 1,5\%. Hanya ada tiga bank yang mencapai standar minimal.

Secara teoritis faktor yang dinilai menentukan profitabilitas perbankan adalah rasio kecukupan modal atau CAR (Chowdhury \& Rasid, 2015:379). Faktor penting lainnya yang menentukan adalah biaya operasional atau BOPO yang menggambarkan keefisienan dalam operasional bank (Abdillah, dkk, 2016:145). Jika semakin besar jumlah biaya operasi (BOPO) maka semakin rendah ROA, karena bank yang produktif dan efisien harus dapat menjaga biaya operasi mereka tetap minimum.

Hasil pengujian pengaruh CAR
dan BOPO terhadap ROA sesungguhnya dapat dijadikan alat uji, apakah perbankan syariah masih bertahan dengan pendekatan intermediasi bank atau justru sudah mempraktekan prinsip bagi hasil. Postulat yang dipakai dalam menganalisis pengaruh kedua faktor ini terhadap profitabilitas adalah "kesamaan penyaluran pembiayaan perbankan syariah dengan perbankan konvensional". Jika hasilnya berpengaruh, maka dapat diartikan praktek perbankan syariah di Indonesia masih sama dengan Bank Konvensional. Sementara, jika tidak berpengaruh, dapat diartikan perbankan syariah di Indonesia sudah menjalankan prinsip bagi hasil, sebagai prinsip utama perbankan syariah.

Sesuai dengan uraian di atas, maka rumusan masalah yang diajukan dalam penelitian ini adalah:

1. Bagaimana gambaran kecukupan modal (CAR) Bank Umum Syariah di Indonesia tahun 2012-2017.

2. Bagaimana gambaran biaya operasional bank (BOPO) Bank Umum Syariah di Indonesia tahun 2012-2017.

3. Bagaimana gambaran tingkat profitabilitas (ROA) Bank Umum Syariah di Indonesia tahun 2012-2017.

4. Bagaimana faktor kecukupan modal (ROA) dan biaya operasional bank (BOPO) mempengaruhi tingkat profitabilitas (ROA) Bank Umum Syariah di Indonesia tahun 2012-2017.

Dengan rumusan masalah tersebut di atas, maka penelitian ini diharapkan selain mampu menggambarkan masing masing faktor dan menemukan pengaruh CAR dan BOPO terhadap ROA sebagai hasil penelitian, juga mampu melakukan pengujian apakah praktek perbankan syariah di Indonesia sudah menjalankan prinsip bagi hasil atau belum.

METODE, UJI HIPOTESIS DAN HASIL PENELITIAN 
Metode yang digunakan dalam penelitian ini adalah metode deskriptif dan metode verifikatif. Dengan populasi seluruh Bank Umum Syariah di Indonesia selama tahun 2012-2017 yakni berjumlah 13 bank. Adapun sampel yang digunakan adalah purposive sampling dengan kriteria Bank Umum Syariah yang secara berturut turut mempublikasikan laporan keuangan selama tahun 2012-2017. Ats kriteria tersebut diperoleh 11 bank. Dengan demikian data yang dianalisis adalah data panel sebanyak 66 data.

Teknik analisis data yang digunakan adalah analisis deskriptif dan analisis regresi. Dalam analisis deskriptif guna untuk mengetahui bagaimana gambaran CAR, BOPO dan ROA pada Bank Umum Syariah tahun 2012-2017. Kemudian analisis regresi dilakukan untuk menguji hipotesis dalam penelitian ini, dimana peneliti menggunakan analisis regresi berganda data panel, dengan tahapan sebagai berikut: (1) pemilihan teknik estimasi regresi data panel melalui uji chow dan Hausman; (2) pengujian asumsi klasik regresi berganda data panel; (3) pengujian hipotesis.

Hasil penelitian menunjukan bahwa gambaran rasio kecukupan modal (CAR) bank umum syariah selama periode 2012-2017 secara keseluruhan yang memenuhi standar (8\%) kriteria nilai CAR. Bank yang memilki perolehan CAR paling tinggi adalah PT Maybank Syariah yaitu
57,45\%. Sedangkan CAR terendah adalah PT Bank Muamalat Indonesia yaitu $13,52 \%$.

Pada biaya operasional (BOPO), secara keseluruhan jika dilihat dari rata-rata BOPO setiap bank selama periode 2012 - 2017, tidak terdapat bank yang dikategorikan sehat berdasarkan efisiensi biaya operasionalnya. Seluruh bank syariah melebihi standar rasio BOPO, yaitu $87 \%$, sebagaimana ditetapkan BI melalui Surat Edaran No. 13/24/DPNP tanggal 25 Oktober 2011.

Pada tingkat profitabilitas (ROA) sebagaimana juga di ungkap di tabel 1.1 di bagian pendahuluan, menunjukan hanya ada tiga bank yang memenuhi standar minimal BI. Sisanya yang lain masih di bawah standar yang ditetapkan BI.

Pada pengujian hipotesis dilakukan sejumlah tahapan uji asumsi klasik. Pertama adalah uji normalitas. Dengan menggunakan Software Eviews 9 diperoleh hasil nilai uji Jarque-Bera (JB) sebesar $43.43145 \leq$ nilai $\left(\chi_{\text {tabel }}^{2}\right)$ sebesar 82.52873, maka dapat disimpulkan bahwa data berdistribusi normal.

Kedua adalah uji multikolinearitas, yang bertujuan untuk menguji apakah model regresi ditemukan adanya korelasi antar variabel independen. Dalam penelitian ini multikolinearitas dengan melihat angka koefisien korelasi antar variabel independen. Jika angka tersebut melebihi 0,8 
maka diduga adanya multikolinieritas. Dalam penelitian ini, uji multikolinieritas yang dihasilkan adalah -0,125569 yang berarti di bawah 0,8. dengan demikian dapat disimpulkan bahwa data pada penelitian ini bebas multikolinearitas.

Ketiga, uji heteroskedastisitas. Dalam penelitian dengan melihat grafik Scatter Plot. Cara ini digunakan untuk mendeteksi adanya heterokedastisitas yaitu melihat ada tidaknya pola tertentu pada scatter plot yang menunjukkan hubungan antara Regression Stundentized Residual (SRESID) dengan Regression Standarized Predicted Value (ZPRED). Hasil pengujian menggunakan grafik scatter plot menunjukan bahwa titik-titik data menyebar secara acak dan tersebar juga tidak membentuk pola tertentu. Hal ini dapat disimpulkan bahwa tidak terjadi masalah heteroskedastisitas pada model regresi dalam penelitian ini.

Keempat, uji autokorelasi. Pengujian ini menggunakan model Durbin Watson (DW test), yang membandingkan nilai DW hitung dengan nilai $\mathrm{dL}$ dan $\mathrm{dU}$ dalam tabel Durbin Watson dengan taraf signifikansi $5 \%, \mathrm{n}=66$ dan $\mathrm{k}=2$ yaitu masing-masing nilainya sebesar 1.5395 dan 1.6640. Dalam penelitian ini, uji autokorelasi yang dihasilkan adalah sebesar 2.076531 berada pada daerah $\mathrm{dU} \leq \mathrm{d} \leq 4-\mathrm{dU}$ yang artinya $1.6640 \leq 2.0765 \leq 2.4605$, sehingga dapat disimpulkan bahwa data penelitian ini tidak terdapat autokorelasi.

Selanjutnya, berdasarkan Uji Chow dan Uji Hausman, dapat ditarik kesimpulan bahwa model regresi yang paling tepat untuk digunakan dalam penelitian ini adalah model Fixed Effect. Berikut adalah hasil regresi data panel dengan menggunakan model Fixed Effect.

Berdasarkan model tersebut, dapat diketahui hasil sebagai berikut: $\mathrm{ROA}=5.260364+0.170990 \mathrm{CAR}-$ $0.089233 \mathrm{BOPO}$

Selanjutnya untuk menguji keberartian model dilakukan uji koefisien regresi keseluruhan (Uji F) pada tingkat signifikansi 5\%. Diperoleh hasil nilai $F_{\text {hitung }}$ sebesar 19.14831. Sedangkan nilai $F_{\text {tabel }}$ pada saat tingkat signifikansi 5\%, $\mathrm{k}-1=3-1=2, \quad \mathrm{n}-\mathrm{k}=66-3=63, \quad$ maka diperoleh nilai $F_{\text {tabel }}$ sebesar 3.14. Sehingga dapat diketahui bahwa $\mathrm{F}_{\text {hitung }}>\mathrm{F}_{\text {tabel, }}$ yang artinya kedua variabel yaitu CAR dan BOPO merupakan faktor penentu dari tingkat profitabilitas (ROA) Bank Umum Syariah di Indonesia untuk tahun 2012-2017.

Dari hasil uji hipotesis tersebut dapat dijelaskan bahwa temuan ini sejalan dengan kondisi umum perbankan syariah di beberapa negara seperti bank syariah di di Kenya (Aduda \& Gitonga, 2011), di Saudi Arabia dan Jordania (Almazari, 2014), di Banglades (Noman, 
2015), di Asia Afrika (Chowdhury \& Rasid, 2015), di Pakistan (Akhtar, et al, 2011). Bahkan secara khusus, penelitian ini memiliki konsistensi dengan penelitian terdahulu pada bank umum syariah di Indonesia. Misalnya, penelitian Stiawan (2010), yang mengambil data tahun 2005-2008. Muliawati (2015) yang mengambil data pada tahun 2011-2013. Jaelani (2015) yang mengambil data paling panjang yaitu tahun 2002-2013. Said \& Ali (2016) yang mengambil data pada tahun 2011-2014. Abdillah, dkk (2016) yang menggunakan tahun penelitian 2008-2015, serta Rahim (2017) yang mengambil data pada tahun 2012-2015. Keseluruhan penelitian-penelitian tersebut menunjukan bahwa kedua faktor tersebut CAR dan BOPO merupakan dua faktor yang menentukan tingkat profitabilitas (ROA) pada Bank Umum Syariah baik di Indonesia maupun beberapa negara islam lainnya.

Hasil ini jika dikonfirmasikan dengan teori intermediasi bank, menunjukan bahwa profitabilitas perbankan syariah hampir di seluruh negara berasal dari praktek yang berasal dari penyaluran pembiyaan seperti yang juga di praktekan oleh perbankan konvensional pada umumnya. Oleh sebab itu maka adanya "kesamaan penyaluran pembiayaan perbankan syariah dengan perbankan konvensional", dapat diartikan perbankan syariah di
Indonesia belum sepenuhnya menjalankan prinsip bagi hasil, sebagai prinsip utama perbankan syariah.

\section{SIMPULAN DAN SARAN}

Berdasarkan hasil penelitian dan pembahasan maka dapat disimpulkan:

1. Kecukupan modal pada Bank Umum Syariah di Indonesia tahun 2012-2017 telah memenuhi modal minimum yang wajib dimiliki sesuai aturan Bank Indonesia.

2. Biaya operasional pada Bank Umum Syariah di Indonesia tahun 2012-2017 masih belum memenuhi standar minimum BOPO yang ditetapkan Bank Indonesia.

3. Profitabilitas pada Bank Umum Syariah di Indonesia tahun 2012-2017, menunjukkan sebanyak 10 dari 11 bank secara keseluruhan berada di bawah standar Bank Indonesia, bahkan beberapa bank menunjukkan data ROA yang negatif.

4. Kecukupan modal dan biaya operasional merupakan dua faktor yang menentukan atas tingkat profitabilitas pada Bank Umum Syariah di Indonesia

5. Perbankan syariah di Indonesia masih terjebak dalam fungsi penyaluran pembiayaan yang sama dengan bank konvensional dan itu berarti belum sepenuhnya menjalankan prinsip bagi hasil, 
sebagai prinsip utama perbankan syariah.

Adapun saran yang dapat diajukan adalah perbankan syariah di Indonesia diharapkan mulai mengembangkan prinsip bagi hasil dalam praktek pembiayaan, yang selama ini praktek bagi hasil ini baru dalam penyimpanan dana oleh nasabah. Hal ini sebagi bentuk dari konsekuensi dari ciri utama perbankan syariah itu sendiri. walaupun mungkin diawal agak sulit, namun prinsip bagi hasil ini justru yang diharapkan menjadi identitas utama perbankan syariah, tentu pada akhirnya akan berjalan secara lebih baik.

Selanjutnya untuk penelitian selanjutnya disarankan untuk meneliti kelompok bank syariah pada jenis bank perkreditan rakyat syariah dan unit usaha syariah. Hal ini untuk mengkonfirmasi temuan penelitian yang sudah dilakukan. Harapannya akan semakin menguatkan saran kepada pelaku perbankan syariah dalam menjalankan praktek bagi hasil (loss profit sharing).

\section{DAFTAR PUSTAKA}

Abdillah, R., Hosen, M. N., \& Muhari, S. (2016). The Determinants Factor of Islamic Bank's Profitability and Liquidity in Indonesia. Knowledge

Horizons. Economics, 8(2), 140.

Aduda J and Gitonga J (2011) The relationship between credit risk management and profitability among the commercial banks in Kenya. Journal of Modern Accounting and Auditing 7(9): 934.

Akhtar M, Ali K and Sadaqat S (2011) Factors Influencing the Profitability of Islamic Banks of Pakistan. International Research Journal of ... 66(66): 1-8. Available from: http://joc.hcc.edu.pk/faculty_p ublications/IRJFE 66 12.pdf.

Al-Harran, S. (1995) Leading Issues in Islamic Banking and Finance, editor, Petaling Jaya: Pelanduk Publications.

Alharbi, AT (2015) Determinants of Islamic banks profitability: international evidence. International Journal of Islamic and Middle Eastern Finance and Management: $1-21$.

Almazari AA (2014) Impact of Internal Factors on Bank Profitability: Comparative Study between Saudi Arabia and Jordan. Journal of Applied Finance \& Banking 4(1): 125-140.

Chapra, M. U. (2008). Ethics And Economics: An Islamic Perspective, Islamic Economic Studies. Vol. 16 No. 1 \& 2, Aug. 2008 \& Jan. 2009 available from www.irti.org/English/Research /Documents/IES/076.pdf

\section{ETHICS AND ECONOMICS: AN ISLAMIC PERSPECTIVE}

Chowdhury, M. A. F., \& Rasid, M. E. S. M. (2015). The determinants of the profitability of Islamic 
banks: a cross-sectional study from Asia and Africa. International Journal of Business Globalisation, 15(3), 375-388.

Muliawati, S., \& Khoiruddin, M. (2015). Faktor-faktor Penentu Profitabilitas Bank Syariah Di Indonesia. Management Analysis Journal, 4(1).

Noman, A. H. M. (2015). An Empirical Investigation of the Profitability of Islamic Banks in Bangladesh. Global Journal of Management And Business Research.

Said, M. (2016). An analysis on the factors affecting profitability level of Sharia banking in Indonesia.

Stiawan, A. (2009). Analisis Pengaruh Faktor Makroekonomi, Pangsa Pasar Dan Karakteristik Bank Terhadap Profitabilitas Bank Syariah (Studi Pada Bank Syariah Periode 2005-2008)(Doctoral dissertation, UNIVERSITAS DIPONEGORO).

Jaelani. (2015) Studi Efisiensi Bank Umum Di Indonesia Tahun 2002 - 2013, Komparasi Faktor-Faktor Penjelas Efisiensi Antara Bank Umum Konvensional Dengan Bank Umum Syariah, Disertasi Program Doktor Ilmu Manajemen, Universitas Pendidikan Indonesia.

Peraturan Bank Indonesia No. 9/1/PBI/2007 tentang Sistem Penilaian Tingkat Kesehatan Bank Umum Berdasarkan Prinsip Syariah.
Surat Edaran Bank Indonesia No. 13/24/DPNP tanggal 25

Oktober 2011. 